\title{
Respiratory uptake and elimination of ethylene glycol monoethyl ether after experimental human exposure
}

\author{
D GROESENEKEN, H VEULEMANS, AND R MASSCHELEIN
}

From the Laboratorium voor Arbeidshygiëne en -toxicologie, Afdeling Arbeids- en Verzekeringsgeneeskunde, $K U$ Leuven, B-3000 Leuven, Belgium

ABSTRACT Ten male volunteers were exposed to ethylene glycol monoethyl ether (EGEE) under various conditions of exposure concentration and physical workload. Steady state levels of retention, atmospheric clearance, and rate of uptake were reached immediately after the start of the exposure period for all experimental conditions. Retention was high (64\% in resting condition) and increased as physical exercise was performed during exposure. Atmospheric clearance increased as the pulmonary ventilation rate increased. The rate of uptake was higher as exposure concentration or pulmonary ventilation rate, or both, increased. Individual uptake appeared to be governed mainly by transport mechanisms (pulmonary ventilation or cardiac output or both) and not by anthropometric factors. Respiratory elimination of unchanged EGEE accounted for $\leqslant 0.4 \%$ of the total body uptake. Postexposure breath concentrations declined rapidly during the first minutes after cessation of exposure, after which a much slower decrease was observed. This slow decrease could be described by a regression equation containing two exponential terms indicating that at least two pharmacological compartments are concerned.

In recent years much evidence has become available on the toxicity of ethylene glycol ethers and this has been recently reviewed. ${ }^{12}$ By contrast, data on the toxicokinetics and disposition of glycol ethers are scant. When beagle dogs were exposed to ethylene glycol monoethyl ether acetate (EGEEAc), approximately $70 \%$ of the inhaled vapour was retained at equilibrium (ca $3 \mathrm{~h}$ ). Postexposure breath concentrations declined rapidly indicating a rapid removal of the component from the blood. ${ }^{3}$ When rats were orally dosed with ${ }^{14} \mathrm{C}$-labelled ethylene glycol monomethyl ether (EGME), $50-70 \%$ of the radiolabel was excreted in the urine within 48 hours, mostly in the form of methoxyacetic acid, ${ }^{45}$ whereas $15 \%$ of the radioactivity was identified as the parent compound. ${ }^{5}$ Analogously, when rats were exposed to the ethylether (EGEE), the major urinary metabolite was ethoxyacetic acid and its glycine conjugate. ${ }^{6}$

Depending on the position of the radiolabel, different amounts of ${ }^{14} \mathrm{C}$ were recovered in expired air as ${ }^{14} \mathrm{CO}_{2}$ : when the label was in the ethanol part of the molecule, $5 \%$ appeared as exhaled ${ }^{14} \mathrm{CO}_{2}$ in the first 10 hours, whereas $12-14 \%$ were recovered as ${ }^{14} \mathrm{CO}_{2}$ when the label appeared in the ether group. Only minor fractions in the expired air (0.4-3\%) were identified as the parent compound and there was no indication for the presence of volatile metabolites other than $\mathrm{CO}_{2}{ }^{4-6}$

Accepted 13 January 1986
To date, all pharmacological experiments have been performed on animals and the present study was set up to investigate the respiratory uptake and elimination of EGEE in man under controlled experimental conditions of exposure concentration and physical workload.

\section{Subjects and methods}

\section{SUBJECTS}

Ten healthy male volunteers (aged 19-28) took part in the study after full information and a written consent. They were randomly assigned into two groups (table 1). Both groups were comparable for age $(F=1 \cdot 2$; $\mathrm{NS})$, weight $(\mathrm{F}=0.7 ; \mathrm{NS})$, and height $(\mathrm{F}=1.6 ; \mathrm{NS})$. Body fat content, calculated from the measurement of the skinfold thickness at four different sites (biceps, triceps, subscapula, and suprailiaca) ${ }^{7}$ also did not differ between the groups $(F=2 \cdot 0 ; N S)$.

All the subjects had normal lung function $\left(\mathrm{FEV}_{1}\right.$, VC, TLC). Before and after the study, blood samples

Table 1 General characteristics of the subjects

\begin{tabular}{|c|c|c|c|}
\hline & Group 1 & Group 2 & $F(p)$ \\
\hline & $(n=5)$ & $(n=5)$ & \\
\hline $\begin{array}{l}\text { Age (years) } \\
\text { Weight (kg) } \\
\text { Height (cm) } \\
\% \text { Body fat }\end{array}$ & $\begin{array}{r}23 \pm 4 \\
70.7 \pm 10.1 \\
181.4 \pm 3.7 \\
11.7 \pm 3.5\end{array}$ & $\begin{array}{r}21 \pm 2 \\
66.1 \pm 7.6 \\
178.4 \pm 3.8 \\
8.9 \pm 2.8\end{array}$ & $\begin{array}{l}1.2 \text { (NS) } \\
0.7 \text { (NS) } \\
1.6 \text { (NS) } \\
2.0 \text { (NS) }\end{array}$ \\
\hline
\end{tabular}


were taken for haematological screening tests (blood cell count, haematocrit, haemoglobin) and liver screening tests (LDH, GOT, GPT, $\gamma$-GT). In no case were significant disorders found.

\section{EXPERIMENTAL CONDITIONS}

A set of five different experiments was designed with varying exposure concentrations or workload (fig 1). The exposure period in each experiment was standardised to four hours, the equivalent of half a workshift. At the end of each hour during exposure a short break of 10 minutes was inserted.

All subjects took part in three experiments according to their group assignment: group 1 performed experiments I to III, group 2 participated in experiments III to V. Between experiments each subject remained unexposed, usually for two or three weeks (minimum: one week).

The exposure concentrations were $10 \mathrm{mg} / \mathrm{m}^{3}, 20$ $\mathrm{mg} / \mathrm{m}^{3}$, and $40 \mathrm{mg} / \mathrm{m}^{3}$ respectively and were held constant during the whole exposure period. The concentrations chosen were near the present day threshold limit value of EGEE $\left(19 \mathrm{mg} / \mathrm{m}^{3}\right){ }^{8}$

The experiments at rest were held with the exposed subject sitting in an arm chair, whereas the standard physical exercises in experiments IV and V were per-

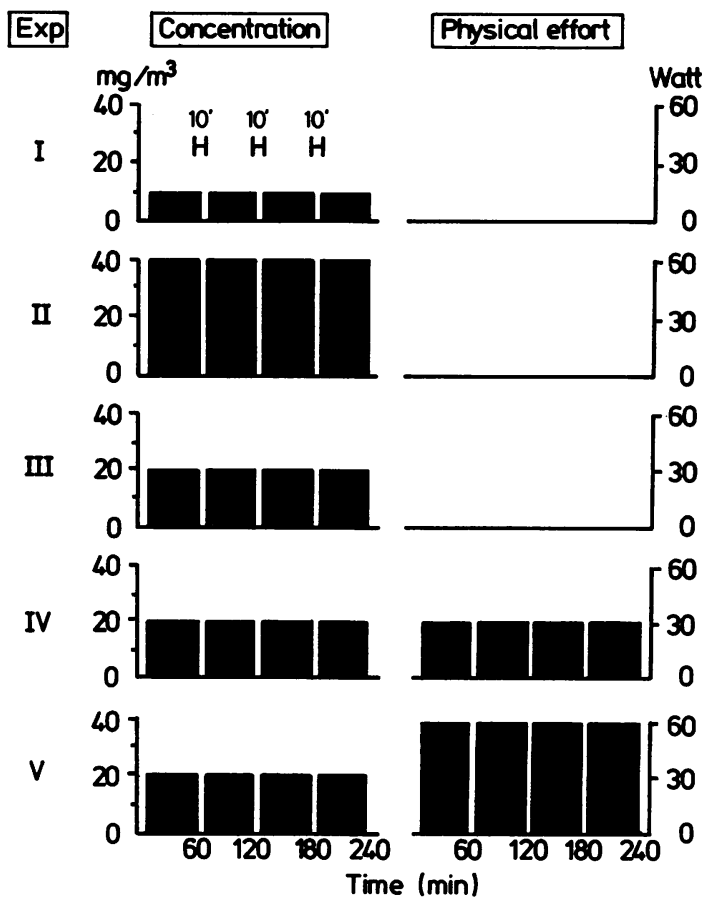

Fig 1 Exposure conditions. formed on a bicycle ergometer (Mynhardt, type KEM2) at a constant pedal frequency $(50 / \mathrm{min})$.

\section{APPARATUS}

The desired solvent concentrations in the air were obtained from a syringe injection generation system as described by Veulemans and Masschelein. ${ }^{9}$ Expired air was taken to an Oxycon-analyser (Mynhardt) for the continuous monitoring of the pulmonary ventilation rate $\left(V_{\mathbf{E}}-\mathrm{BTPS}\right)$ and oxygen consumption ( $\left.\mathrm{VO}_{2}-\mathrm{STPD}\right)$.

During and after the exposure period, the ECG was continuously recorded on a Simpliscriptor EK 100 (Hellige). Heart rate (beats/min) was calculated on the basis of $10 \mathrm{R}-\mathrm{R}$ intervals.

\section{MEASUREMENT OF EGEE IN AIR}

In both inhaled $\left(C_{1}\right)$ and mixed expired air $\left(C_{E}\right)$ EGEE was determined by gas chromatography. Air samples were taken by pumping the air into glass tubes containing $150 \mathrm{mg}$ silica gel in the sampling section (SKC Inc, Palo Alto, CA, USA). The silica gel was desorbed with $1 \mathrm{ml}$ methanol containing $50 \mathrm{mg} / 1$ ethylene glycol monobutyl ether as an internal standard. The desorption efficiency for EGEE was $88 \pm 6 \%(n=15)$.

Gas chromatographic analysis was performed after the injection of $1-5 \mu l$ of the methanolic solution on a CP-WAX $57 \mathrm{CB}$, WCOT fused silica column

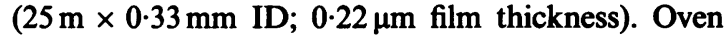
temperature was kept at $30^{\circ} \mathrm{C}$ for 30 seconds and programmed to $90^{\circ} \mathrm{C}$ at a rate of $40^{\circ} \mathrm{C} / \mathrm{min}$. This temperature was held for three minutes. Thereafter, the oven temperature was programmed to $120^{\circ} \mathrm{C}$ at a rate of $10^{\circ} \mathrm{C} / \mathrm{min}$. The gas chromatograph was equipped with a flame ionisation detector and a $\mathrm{CO}_{2}$-cryosystem; the flow rate of the He-carrier gas was $1 \mathrm{ml} / \mathrm{min}$.

\section{TIMING OF THE MEASUREMENTS}

The exposure concentration of EGEE was calibrated before each experiment and checked every hour. Samples of mixed expired air were taken and analysed every 10 minutes during exposure and with a decreasing frequency after the exposure period. During exposure, air samples of 31 were taken; after the exposure period, sample volumes were 7.51 during the first two hours and 151 during the last two hours.

Pulmonary ventilation rate $(\overbrace{E^{-1}} / \mathrm{min})$ and oxygen consumption $\left(\mathrm{VO}_{2}-1 / \mathrm{min}\right)$ were recorded immediately before sampling. Heart rate $\left(\mathrm{HR}-\mathrm{min}^{-1}\right)$ and respiratory frequency $\left(f-\min ^{-1}\right)$ were determined during sampling.

\section{CALCULATIONS}

The absorbed fraction of EGEE was calculated as: 
Retention $\left(R_{E}\right)=\left(C_{1}-C_{E}\right) / C_{I}$

[1]

where: $C_{I}=$ inhaled and $C_{E}=$ exhaled concentration (in $\mathrm{mg} / \mathrm{m}^{3}$ ).

Retention as such does not give the rate of respiratory uptake without the pulmonary ventilation rate.$^{10}$ The uptake can therefore be more adequately measured by using the atmospheric clearance $\left(\mathrm{Cl}_{\mathrm{atm}}\right)$ :

$\mathrm{Cl}_{\mathrm{atm}}(\mathrm{l} / \mathrm{min})=\mathbf{R}_{\mathrm{E}} \cdot \stackrel{\circ}{\mathrm{V}}_{\mathbf{E}}$

where $\mathrm{Cl}_{\mathrm{atm}}$ represents the virtual volume of inspired air from which all the available EGEE is absorbed per unit of time. The uptake rate is then given by:

Uptake rate $(\mu \mathrm{g} / \mathrm{min})=R_{E} \cdot \stackrel{\wp}{V}_{E} \cdot C_{I}$

for $C_{I}$ in $\mu \mathrm{g} / 1$.

Oxygen pulse, an index of cardiac output, was calculated as oxygen consumption per heart beat:

$\mathrm{O}_{2}$-pulse (1) $=\mathrm{V}^{\circ} \mathrm{O}_{2} / \mathrm{HR}$

\section{STATISTICAL ANALYSIS}

The data were analysed using a three way analysis of variance with experimental conditions, exposure time, and subjects as the main sources of variation. Single and multiple linear regression analysis were also used where appropriate.

\section{Results}

\section{RESPIRATORY UPTAKE}

Absorption and exposure time

As shown in fig 2 , for exposure at rest to $20 \mathrm{mg} / \mathrm{m}^{3}$ ethylene glycol monoethyl ether (EGEE), retention $\left(R_{E}\right)$, atmospheric clearance $\left(\mathrm{Cl}_{\mathrm{atm}}\right)$, and rate of uptake seemed to have reached a steady state level immediately after the beginning of exposure and remained unchanged during the whole exposure period $\left(\mathrm{F}=0.8\right.$; $\mathrm{NS}$ for $\mathrm{R}_{\mathrm{E}}, \mathrm{F}=1.2 ; \mathrm{NS}$ for $\mathrm{Cl}_{\mathrm{atm}}$ and $\mathrm{F}=1.0 ; \mathrm{NS}$ for uptake rate). The same time course was observed for the other experimental conditions $\left(\mathrm{F}_{\text {time }} \leqslant 2 \cdot 8 ; \mathrm{NS}\right)$. There was no indication, therefore, for a possible saturation of EGEE under the condi-

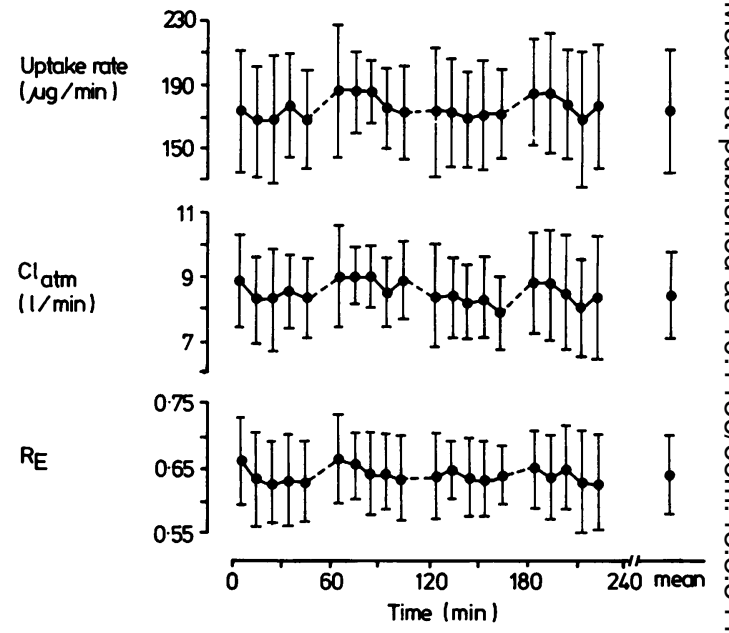

Fig 2 Time course of retention $\left(R_{E}\right)$, atmospheric clearance $\left(C l_{\text {atm }}\right)$, and rate of uptake during exposure to $20 \mathrm{mg} / \mathrm{m}^{3}$

$E G E E$ at rest. Data are mean $\pm S D$ for 10 subjects.

tions used, otherwise a time dependent decrease in retention would have been expected.

\section{Absorption and exposure concentration}

Under resting conditions, an average of $64 \%$ of inhaled EGEE was retained (table 2). $R_{E}$ and $\mathrm{Cl}_{\text {atm }}$ remained unchanged as exposure concentration increased $\left(F=1.6\right.$; NS for $R_{E}$ and $F=2.0$; NS for $\left.\mathrm{Cl}_{\mathrm{atm}}\right)$. The absorbed dose was apparently proportional to the inhaled concentration and a linear relation between uptake rate and exposure concentration was observed:

uptake rate $(\mu \mathrm{g} / \mathrm{min})=7.75 \times \mathrm{C}_{\mathrm{I}}\left(\mathrm{mg} / \mathrm{m}^{3}\right)$

$$
\mathrm{r}=0.95 ; \mathrm{p}<0.001
$$

Absorption and physical exercise

Compared with the resting condition, $\mathrm{Cl}_{\text {atm }}$ and consequently rate of uptake increased $(F=113.5$; $p<0.001$ ) when physical exercise was performed during exposure. This was due not only to an increase in

Table 2 Respiratory function, retention, atmospheric clearance, and rate of uptake for different experimental conditions. (Data are mean \pm SD for five subjects)

\begin{tabular}{|c|c|c|c|c|c|c|c|}
\hline $\begin{array}{l}\text { Experimental } \\
\text { conditions }\end{array}$ & $\begin{array}{l}\text { No } \\
\text { obs }\end{array}$ & $\dot{V}_{E}(l / m i n)$ & $f\left(\min ^{-1}\right)$ & $\dot{V}_{\mathrm{O}_{2}}(l / \min )$ & $R_{E}$ & $C l_{a t m}(l / \min )$ & $\begin{array}{l}\text { Rate } \\
(\mu \mathrm{g} / \mathrm{min})\end{array}$ \\
\hline $\begin{array}{l}\text { Group } 1 \\
10 \mathrm{mg} / \mathrm{m}^{3}-0 \mathrm{~W} \\
20 \mathrm{mg} / \mathrm{m}^{3}-0 \mathrm{~W} \\
40 \mathrm{mg} / \mathrm{m}^{3}-0 \mathrm{~W}\end{array}$ & $\begin{array}{l}100 \\
100 \\
100\end{array}$ & $\begin{array}{l}12.7 \pm 1.6 \\
13.0 \pm 1.6 \\
12.4 \pm 1.6 \\
\text { F }=1.2 \\
\text { NS }\end{array}$ & $\begin{array}{l}16 \cdot 8 \pm 3 \cdot 0 \\
17 \cdot 0 \pm 3 \cdot 2 \\
16.2 \pm 2 \cdot 2 \\
F=0.3 \\
N S\end{array}$ & $\begin{array}{l}0.166 \pm 0.052 \\
0.271 \pm 0.088 \\
0.214 \pm 0.052 \\
F=1.6 \\
N S\end{array}$ & $\begin{array}{l}0.617 \pm 0.071 \\
0.646 \pm 0.064 \\
0.590 \pm 0.062 \\
F=1.6 \\
N S\end{array}$ & $\begin{array}{l}7.90 \pm 1.54 \\
8.45 \pm 1.41 \\
7.34 \pm 1.37 \\
F=2.0 \\
\text { NS }\end{array}$ & $\begin{array}{l}83.7 \pm 21.2 \\
175.4 \pm 37.8 \\
320.7 \pm 72.7 \\
F=80.7 \\
p<0.001\end{array}$ \\
\hline $\begin{array}{l}\text { Group } 2 \\
20 \mathrm{mg} / \mathrm{m}^{3}-0 \mathrm{~W} \\
20 \mathrm{mg} / \mathrm{m}^{3}-30 \mathrm{~W} \\
20 \mathrm{mg} / \mathrm{m}^{3}-60 \mathrm{~W}\end{array}$ & $\begin{array}{l}100 \\
100 \\
100\end{array}$ & $\begin{array}{l}13.1 \pm 2.0 \\
21.8 \pm 3.8 \\
31.3 \pm 4.4 \\
F=172.7 \\
p<0.001\end{array}$ & $\begin{array}{l}14.8 \pm 4.4 \\
17.6 \pm 4.3 \\
19.8 \pm 5.1 \\
F=12.1 \\
p<0.01\end{array}$ & $\begin{array}{l}0.227 \pm 0.072 \\
0.626 \pm 0.232 \\
0.825 \pm 0.244 \\
F=6.1 \\
p<0.05\end{array}$ & $\begin{array}{l}0.633 \pm 0.062 \\
0.696 \pm 0.036 \\
0.706 \pm 0.030 \\
F=6.9 \\
p<0.05\end{array}$ & $\begin{array}{l}8.25 \pm 1.41 \\
15.18 \pm 2.68 \\
22.13 \pm 3.30 \\
F=113.4 \\
p<0.001\end{array}$ & $\begin{array}{l}166.4 \pm 41.3 \\
284.8 \pm 58.8 \\
472.0 \pm 69.5 \\
F=176.9 \\
p<0.001\end{array}$ \\
\hline
\end{tabular}


the pulmonary ventilation rate $(F=172.7 ; p<0.001)$ but also to a slight increase in retention $(F=6.9$; $p<0.05$ ). The increase of $R_{E}$, however, was not proportional to the level of exercise since no difference was found between $30 \mathrm{~W}$ and $60 \mathrm{~W}(\mathrm{~F}=1.0 ; \mathrm{NS})$. Nevertheless, a linear relation between uptake rate and $\mathfrak{V}_{E}$ was found:

$$
\begin{aligned}
& \text { uptake rate }(\mu \mathrm{g} / \mathrm{min})=14.0 \times \stackrel{\circ}{\mathrm{V}}_{\mathrm{E}}(1 / \mathrm{min}) \\
& \mathrm{r}=0.91 ; \mathrm{p}<0.001
\end{aligned}
$$

\section{Factors influencing the individual uptake}

Single regression analysis was performed on pooled data to discover which personal factors contributed to the individual uptake.

Retention was significantly related to $\dot{V}_{\mathbf{E}}$ $(\mathrm{r}=+0.55 ; \mathrm{p}<0.001), \mathrm{VO}_{2}(\mathrm{r}=+0.58 ; \mathrm{p}<0.001)$, heart rate $(\mathrm{r}=+0.55 ; \mathrm{p}<0.001)$ and $\mathrm{O}_{2}$-pulse $(r=+0.56 ; p<0.001)$, the latter being an index of cardiac output. Atmospheric clearance was also related to these parameters $(r=+0.99 ; p<0.001$ for $\hat{\mathrm{V}}_{\mathrm{E}}, \mathrm{r}=+0.82 ; \mathrm{p}<0.001$ for $\mathrm{VO}_{2}, \mathrm{r}=+0.89$; $\mathrm{p}<0.001$ for HR and $\mathrm{r}=+0.67 ; \mathrm{p}<0.001$ for $\mathrm{O}_{2}$-pulse) and to respiratory frequency $(\mathrm{r}=+0.46$; $\mathrm{p}<0.001)$, height $(\mathrm{r}=-0.24 ; \mathrm{p}<0.01)$, and body fat content $(r=-0.25 ; \mathrm{p}<0.01)$. Uptake rate correlated with $\stackrel{\mathrm{V}}{\mathrm{E}}_{\mathrm{E}}(\mathrm{r}=+0.77 ; \mathrm{p}<0.001), \quad \mathrm{VO}_{2}$ $(r=+0.63 ; p<0.001)$, heart rate $(r=+0.70$; $\mathrm{p}<0.001), \mathrm{O}_{2}$-pulse $(\mathrm{r}=+0.50 ; \mathrm{p}<0.001)$, respiratory frequency $(\mathrm{r}=+0.26 ; \mathrm{p}<0.01)$, height $(r=-0.19 ; p<0.05)$ and with inhaled concentration of $\operatorname{EGEE}(r=+0.48 ; p<0.001)$.

In multiple linear regression analysis, using a step up procedure, only the correlation with $\grave{\mathrm{V}}_{\mathrm{E}}$, respiratory frequency ( $f$ ), and $C_{1}$ persisted for rate of uptake and with $\grave{V}_{\mathrm{E}}$, $\mathrm{f}$, and $\mathrm{O}_{2}$-pulse for retention and atmospheric clearance.

$$
\begin{aligned}
& R_{E}=0.63+0.0043 \stackrel{\vee}{E}_{E}(1 / \mathrm{min})-0.0058 \mathrm{f}\left(\min ^{-1}\right)+ \\
& 10.0 \mathrm{O}_{2} \text {-pulse (1) } \\
& \begin{array}{lll}
\mathrm{r}=0.42 & \mathrm{r}=0.37 & \mathrm{r}=0.35 \\
\mathrm{p}<0.001 & \mathrm{p}<0.001 & \mathrm{p}<0.001 \\
& \mathrm{R}=0.69 ; \mathrm{p}<0.001
\end{array} \\
& \mathrm{Cl}_{\text {atm }}(1 / \mathrm{min})=-0.91+0.755 \stackrel{\mathrm{V}}{\mathrm{E}}(1 / \mathrm{min})-0.073 \mathrm{f} \\
& \left(\min ^{-1}\right)+1386 \mathrm{O}_{2} \text {-pulse (1) } \\
& \begin{array}{lll}
r=0.99 & r=0.33 & r=0.34 \\
\mathrm{p}<0.001 & \mathrm{p}<0.001 & \mathrm{p}<0.001 \\
& \mathrm{R}=0.99 ; \mathrm{p}<0.001
\end{array}
\end{aligned}
$$

Uptake rate $(\mu \mathrm{g} / \mathrm{min})=-136.5+16.7 \mathrm{~V}_{\mathrm{E}}(1 / \mathrm{min})-$ $4.56 \mathrm{f}\left(\mathrm{min}^{-1}\right)+7.71 \mathrm{C}_{\mathrm{I}}\left(\mathrm{mg} / \mathrm{m}^{3}\right)$

$$
\begin{array}{lll}
r=0.97 & r=0.48 & r=0.95 \\
p<0.001 & p<0.001 & p<0.001 \\
& R=0.98 ; p<0.001
\end{array}
$$

Individual respiratory uptake of EGEE is thus governed mainly by pulmonary ventilation, corrected for respiratory frequency, and the concentration of EGEE in the air.

\section{RESPIRATORY ELIMINATION}

Respiratory elimination and exposure concentration

The postexposure breath concentration of EGEE was measured at regular times for four hours after the exposure period. The time course of respiratory elimination after exposure at rest to different concentration is depicted in fig 3.

Exhaled concentrations declined quickly during the first minutes, since the concentration after 7.5 minutes was only $1.5 \pm 0.6 \%$ of the exhaled concentration during exposure. Thereafter a much slower decrease was observed to levels near the detection limit of the method. This slow decrease could best be represented by a regression equation containing at least two exponential terms:

$C_{E}\left(\mu g / m^{3}\right)=114 e^{-0.117 t}+25 \mathrm{e}^{-0.0065 t}$ after exposure to $10 \mathrm{mg} / \mathrm{m}^{3}$

$C_{E}\left(\mu \mathrm{g} / \mathrm{m}^{3}\right)=218 \mathrm{e}^{-0.128 \mathrm{t}}+36 \mathrm{e}^{-0.0070 t}$ after exposure to $20 \mathrm{mg} / \mathrm{m}^{3}$

$C_{E}\left(\mu \mathrm{g} / \mathrm{m}^{3}\right)=417 \mathrm{e}^{-0.149 \mathrm{t}}+59 \mathrm{e}^{-0.0068}$ after exposure to $40 \mathrm{mg} / \mathrm{m}^{3}$

Postexposure breath concentrations were higher $(F=6.1 ; p<0.05)$ as exposure concentration and consequently uptake increased.

\section{Respiratory elimination and physical exercise}

Exhaled EGEE concentration after exposure during physical exercise was measured with the subject sitting in an arm chair.

Respiratory elimination after exposure to 20 $\mathrm{mg} / \mathrm{m}^{3}$ under physical workload showed a time course similar to that in the resting condition (fig 4). The fast drop of postexposure breath concentration during the first minutes was followed by a slower

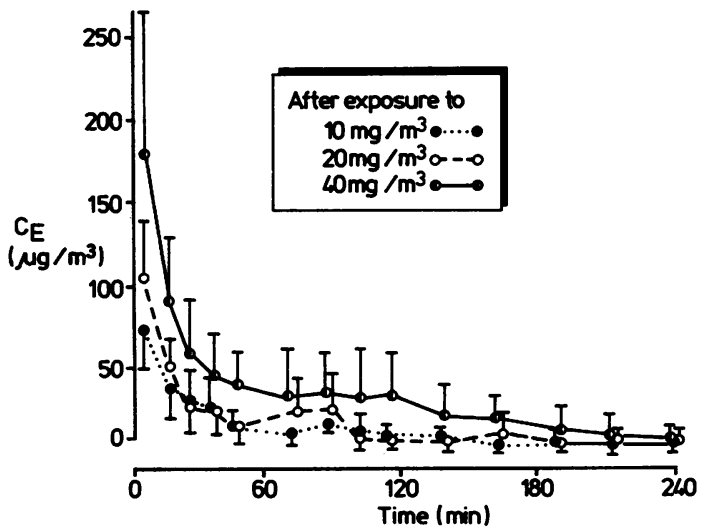

Fig 3 Respiratory elimination of EGEE after exposure at rest. Data are mean $\pm S D$ for five subjects. 


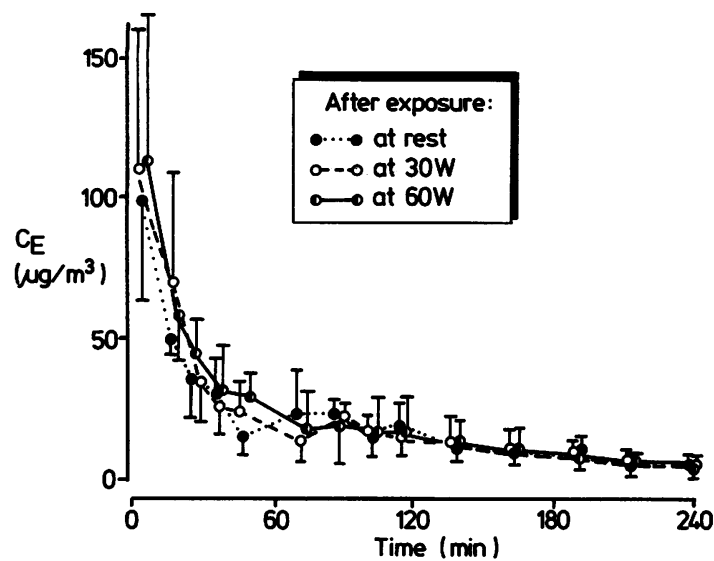

Fig 4 Respiratory elimination of EGEE after exposure to $20 \mathrm{mg} / \mathrm{m}^{3}$ during physical exercise. Data are mean $\pm S D$ for five subjects.

decrease that could again be represented by at least two exponential terms:

$C_{E}\left(\mu \mathrm{g} / \mathrm{m}^{3}\right)=191 \mathrm{e}^{-0.122 t}+34 \mathrm{e}^{-0.0074 t}$ after exposure at rest

$\mathrm{C}_{\mathrm{E}}\left(\mu \mathrm{g} / \mathrm{m}^{3}\right)=224 \mathrm{e}^{-0.108 t}+33 \mathrm{e}^{-0.0069 t}$ after exposure at $30 \mathrm{~W}$

$C_{E}\left(\mu g / m^{3}\right)=246 \mathrm{e}^{-0.122 t}+44 \mathrm{e}^{-0.0084 t}$ after exposure at $60 \mathrm{~W}$

Postexposure breath concentrations tended to be higher as the physical workload increased but this tendency was not significant $(F=0 \cdot 2 ; N S)$.

\section{Total respiratory elimination}

The total amount of unchanged EGEE eliminated through the lungs was calculated by integration of the elimination curves $\left(\mathrm{C}_{\mathrm{E}} / \mathrm{V}_{\mathrm{E}}\right.$ versus time). The respiratory elimination of EGEE accounted for $\leqslant 0.4 \%$ of total body uptake $(0.2-0.4 \%$ for exposure at rest and $0 \cdot 1-0 \cdot 15 \%$ for exposures during physical exercise).

Multiple linear regression analysis on the pooled data showed that the total amount of EGEE eliminated was positively correlated with the inspired concentration during exposure and with the body fat content (BFC) and negatively with the $\mathrm{O}_{2}$-pulse during elimination and with the height of the subject:

$$
\begin{gathered}
\mu \mathrm{g} \text { exhaled }=634+2.33 \mathrm{C}_{\mathrm{I}}\left(\mathrm{mg} / \mathrm{m}^{3}\right)-5772 \\
\mathrm{O}_{2} \text {-pulse }(1)-3.41 \text { height }(\mathrm{cm}) \\
\mathrm{r}=0.65 \mathrm{r}=0.23 \quad \mathrm{r}=0.39 \\
\mathrm{p}<0.001 \mathrm{p}<0.05 \mathrm{p}<0.001 \\
+2.64 \mathrm{BFC}(\%) \\
\mathrm{r}=0.28 \\
\mathrm{p}<0.01 \\
\mathrm{R}=0.72 ; \mathrm{p}<0.001 .
\end{gathered}
$$

\section{Discussion}

This inhalation study shows that, in man, EGEE is rapidly absorbed through the lungs. About $64 \%$ of the inhaled vapour was retained at rest. This steady $\overrightarrow{0}$ state level seemed to be reached immediately after the $\frac{C}{0}$ start of exposure for all experimental conditions. By $\bar{\sigma}$ contrast, alveolar retention $\left(R_{A}\right)$ of EGEEAc reached $\bar{\nabla}$ a steady state level only after about three hours when $\cong$ beagle dogs were exposed to a concentration of $50 \mathrm{c}$ ppm $\left(270 \mathrm{mg} / \mathrm{m}^{3}\right){ }^{3}$ In our experiments, however, $\vec{\circ}$ retention was calculated from the concentrations in $\vec{\overrightarrow{ }}$ mixed expired air. Due to the high solubility of EGEE $\vec{\sigma}^{\circ}$ in aqueous media, low alveolar concentrations are $O$ expected. ${ }^{11}$ As a consequence, the relative con- $\frac{\mathbb{D}}{3}$ tribution of the alveolar concentration to the mixed expired concentration would be small so that rela- $\underset{\infty}{\infty}$ tively great variations of alveolar concentration of would result in small or undetectable changes in $\vec{A}$ mixed expired concentration.

Retention was not affected by the exposure concentrations used suggesting that the metabolic clearance capacity was not saturated at this concentration range. Had this been the case, this would have $\stackrel{5}{\rightarrow}$ resulted in more rapidly increasing blood concen- $\vec{P}$ trations with a higher $\mathbf{C}_{\mathbf{l}}$ and consequently a decrease $\stackrel{0}{\circ}$ in retention. On the other hand, steady state retention was higher during exercise than during rest. For a series of non-polar solvents, retention decreased during physical exercise, ${ }^{9-12}$ this decrease being dependent on the solubility of the solvent in aqueous media: the higher the solubility the smaller the $\stackrel{\varnothing}{\propto}$ decrease on retention. ${ }^{11}$ During physical work of low $\overrightarrow{\vec{B}}$ intensity, pulmonary ventilation increased (table 2) $\frac{9}{3}$ and this is primarily due to an increased tidal volume. Since the relative contribution of respiratory dead space decreased with increasing tidal volume, a steeper increase of the alveolar ventilation compared with the ventilation of the respiratory dead space would be expected. ${ }^{13}$ An increase in the alveolar vol- 3 ume relative to the total expired volume could cause a fall of the mixed exhaled concentration $\left(C_{E}\right)$ and, consequently, a rise of the total retention $\left(R_{E}\right)$. This effect would overcome a possible decrease in alveolar retention $\left(\mathbf{R}_{\mathrm{A}}\right)$, which is to be expected from the higher blood concentrations as a result of a higher uptake rate during exercise.

At rest, atmospheric clearance remained un- $N$ changed as exposure concentration increased. During N exercise, however, atmospheric clearance increased linearly with an increase in the pulmonary ventilation rate. The rate of uptake increased as exposure concentration or physical workload, or both, increased, the latter being due to an increased pulmonary ventilation rate. Therefore the exposure concentration alone provides no reliable measure of the absorbed 
dose. Atmospheric clearance and uptake rate seemed to be dependent only on transport mechanisms (pulmonary ventilation rate and cardiac output, measured by oxygen pulse) since no contribution of anthropometric data or body fat content could be found in multiple linear regression analysis for the conditions used.

The postexposure breath concentration of EGEE showed a rapid decline during the first minutes after the cessation of exposure. This fast drop may be assigned mainly to the wash out of the respiratory dead space. The slower decrease may be represented by a regression equation containing two exponential terms indicating that at least two pharmacological compartments are involved in the respiratory elimination of EGEE. Since the total amount of unchanged EGEE eliminated through the lungs accounts for $\leqslant 0.4 \%$ of total body uptake, however, respiratory elimination seems to be only a minor route of EGEE disposition. This observation is in agreement with the results of Miller $e t$ al where only $0.4 \%$ of administered ${ }^{14} \mathrm{C}$-EGME was recovered as the parent compound or as volatile metabolites other than $\mathrm{CO}_{2}$ in the expired air of treated rats. ${ }^{4}$ The low concentrations of EGEE in expired air after the exposure period could be at least partially explained by the high solubility in aqueous media and consequently a high blood/gas partition coefficient of EGEE. There was no indication from the chromatograms for the presence of volatile organic compounds other than EGEE in the expired air.

Individual postexposure breath concentrations showed a great spread resulting partially from systematic interindividual differences independent of exposure conditions. A contribution of methodology to the large variations, however, cannot be excluded since measured concentrations were near the detection limit of the method. Therefore discrimination between the various exposure conditions was not always possible even when average data were considered. As the rate of uptake increases, higher postexposure breath concentrations may be expected. This was found to be significant $(p=0.026)$ only for the experiments at rest when exposed to increasing concentrations. Nevertheless, individual respiratory elimination seems to be more affected by anthropometric data than the individual uptake as shown by multiple regression analysis.

We are indebted to $\mathrm{Dr} W$ Goossens from the department of haematology for performing the hae- matological screening tests and to Dr W Lissens from the Central Laboratory for performing the liver tests. We are also grateful to Mrs A Veirman, Ms A Mannaerts, and Ms $H$ Janssens for the excellent technical help and to Mrs M Rogghe for preparing the manuscript. This work was supported by the Institute of Hygiene and Epidemiology of the Belgian Ministry of Public Health, contract No G/1701/1983-4.

Request for reprints to: D Groeseneken, Laboratorium voor Arbeidshygiëne en-toxicologie, Provisorium I, Minderbroedersstraat 17, B-3000 Leuven, Belgium.

\section{References}

${ }^{1}$ Rowe VK, Wolf MA. Derivatives of glycols. In: Clayton GD, Clayton FE, eds. Patty's industrial hygiene and toxicology. Vol 2C. 3rd rev. New York: Wiley. 1982: 3909-4052.

${ }^{2}$ Hardin BD, Lyon JP. Summary and overview: NIOSH symposium on toxic effects of glycol ethers. Environ Health Perspect 1984;57:273-5.

${ }^{3}$ Guest D, Hamilton ML, Deisinger PJ, DiVincenzo GD. Pulmonary and percutaneous absorption of 2-propoxyethyl acetate and 2-ethoxyethyl acetate in beagle dogs. Environ Health Perspect 1984;57:177-83.

${ }^{4}$ Miller RR, Hermann EA, Langvardt PW, McKenna MJ, Schwetz BA. Comparative metabolism and disposition of ethylene glycol monomethyl ether and propylene glycol monomethyl ether in male rats. Toxicol Appl Pharmacol 1983;67:229-37.

${ }^{5}$ Foster PMD, Creasy DM, Foster JR, Gray TJB. Testicular toxicity produced by ethylene glycol monomethyl and monoethyl ethers in the rat. Environ Health Perspect 1984;57:207-17.

${ }^{6}$ Cheever KL, Plotnick HB, Richards DE, Weigel WW. Metabolism and excretion of 2-ethoxyethanol in the adult male rat. Environ Health Perspect 1984;57:241-8.

${ }^{7}$ Durnin JVGA, Womersley J. Body fat assessed from total body density and its estimation from skinfold thickness: measurements on 481 men and women aged from 16 to 72 years. Br J Nutr 1974;32:77-97.

${ }^{8}$ American Conference of Governmental Industrial Hygienists. Threshold limit values for chemical substances in work air adopted by ACGIH for 1984-5. Cincinnati: ACGIH, 1984.

${ }^{9}$ Veulemans H, Masschelein R. Experimental human exposure to toluene. I. Factors influencing the individual respiratory uptake and elimination. Int Arch Occup Environ Health 1978;42:91-103.

${ }^{10}$ Monster AC, Boersma G, Duba WC. Pharmacokinetics of trichloroethylene in volunteers, influence of workload and exposure concentration. Int Arch Occup Environ Health 1976;38:87-102.

${ }^{11}$ Åstrand I. Uptake of solvents in the blood and tissues of man. A review. Scand J Work Environ Health 1975;1:199-218.

12 Veulemans H, Van Vlem E, Janssens H, Masschelein R, Leplat A. Experimental human exposure to $n$-hexane. Study of the respiratory uptake and elimination, and of n-hexane concentrations in peripheral venous blood. Int Arch Occup Environ Health 1982;49:251-63.

${ }^{13}$ Åstrand P-O, Rodahl K. Textbook of work physiology. Physiological bases of exercise. 2nd ed. New York: McGraw-Hill Book Company, 1977: 227-35. 